\title{
30 anos de PPGLL e os rumos da Leitura
}

\author{
DOI: $10.28998 / 2317-9945.2019 \mathrm{n} 63 \mathrm{p} 4-6$
}

Após a publicação do número 60 da Leitura, seguido por dois números temáticos, esta edição volta a reunir trabalhos submetidos em regime de fluxo contínuo, com estudos que partem das mais variadas perspectivas, oriundos de autores de distintas partes do país e pesquisadores locais. São 22 novos artigos divulgados à comunidade acadêmica - além de um ensaio e uma tradução -, quatro deles de autoria de docentes e discentes do Programa de Pós-graduação em Linguística e Literatura (PPGLL), representando três das atuais quatro linhas de pesquisa existentes. Com a compilação de trabalhos desta natureza, seguindo a nova política editorial da Leitura, tem-se em vista a multiplicidade de temas existentes em um campo tão vasto como o de Linguística e Literatura.

A importância desta edição também pode ser traduzida quantitativamente: para que todos os textos que compõem este número viessem a circular, nada menos que 91 pessoas estiveram envolvidas, entre editores, colaboradores da revista, membros do Conselho Editorial, bem como os nossos pareceristas ad hoc. Registramos um agradecimento especial a este último grupo que, comprometido com a qualidade dos trabalhos publicados, realizou com responsabilidade a avaliação dos manuscritos.

Esta edição é também marcada por muitas celebrações: a primeira delas diz respeito aos 30 anos de inauguração do PPGLL da Universidade Federal de Alagoas (Ufal), o primeiro programa de pós-graduação stricto sensu da instituição (MOURA, 2009, p. 7), fundado pela professora Denilda Moura. A Leitura, criada no ano de 1987 e vinculada, inicialmente, ao Departamento de Letras Clássicas e Vernáculas do Centro de Ciências Humanas, Letras e Artes, passou a pertencer ao PPGLL em 1994, ao qual está vinculada desde então. Em seus 63 números, a Leitura não apenas colocou em circulação os estudos de pesquisadores de diferentes partes do Brasil e exterior, como também impulsionou a pesquisa local, veiculando e divulgando artigos científicos de mestrandos, doutorandos, egressos e docentes do Programa.

O segundo motivo de comemoração, diretamente alinhado com o anterior, diz respeito ao projeto de extensão Memória da Revista Leitura, desenvolvido nos primeiros meses de 2019, como forma de recuperar sua história e traçar perspectivas futuras. O projeto envolveu alunos e docentes e, com o apoio da Fundação de Amparo à Pesquisa do Estado de Alagoas (Fapeal), auxiliou a Leitura a resgatar os números que até então só podiam ser encontrados no formato impresso. Um verdadeiro garimpo foi realizado pelos editores e, por meio da Fundação, com a ajuda da professora Francisca Rosaline Leite Mota, chefe do arquivo da Fapeal e docente da Pós-graduação em Ciência da Informação da Ufal, os 44 primeiros números foram digitalizados e disponibilizados na página da revista, com seus respectivos DOI. No total, são 22 anos de história recuperados e 371 textos que voltam a circular para contribuir com as pesquisas na área. Com a conclusão desta tarefa, a Leitura busca não apenas consolidar-se em seu meio, mas firmar bases como forma de perenizar-se, razão de ser de todo periódico científico (PIOTR, 2009, p. 88). Não poderíamos deixar de agradecer, além das instituições e pessoas supracitadas, aos discentes Danillo Lins, Heitor Monteiro e Nicolas Colatino, sem os quais não seria possível concluir esta empreitada. 
Outro motivo de grande celebração é que a Leitura vem se consolidando como um espaço significativo de circulação do conhecimento na área, sendo hoje a terceira revista mais bem qualificada no estado de Alagoas, de acordo com o estudo de Araújo e Pedri (2019, p. 76-78). Em consonância com os instrumentos de avaliação da Capes, vem buscando atender os critérios exigidos para a melhoria de seu Qualis, especialmente no que diz respeito à pontualidade da publicação, à maior transparência quanto a política e processo editoriais, à sua indexação em bases de dados nacionais e internacionais, à pluralidade de autores e instituições participantes de cada edição e, ainda, ao desenvolvimento e otimização de procedimentos internos. Vale ressaltar que tais conquistas foram obtidas, em grande parte, graças à parceria com a Fapeal, que vem colaborando com a produção das últimas edições da Leitura, através de edital de apoio à editoração e publicação de periódicos científicos em Alagoas.

Por fim, registramos uma grande mudança em nosso ritmo de publicações, que será de fundamental relevância para os próximos passos da Leitura: devido ao aumento do número de submissões recebidas e aprovadas, diante do cenário exposto, o Conselho Editorial deliberou pela mudança de sua periodicidade para quadrimestral. Desta maneira, esperamos dar celeridade à divulgação dos trabalhos aceitos, mantendo a qualidade que o periódico vem se esforçando em obter, ampliando o espaço de difusão do conhecimento tanto através de edições de temática livre como também dos já consagrados dossiês, que continuarão sendo publicados. Ao ritmo de três números por ano, a equipe editorial consegue manter foco nas duas formas de publicação.

Diante do cenário ora favorável, convidamos a todos a contemplar este número, desejando uma leitura prazerosa e frutífera, assim como reiteramos nosso convite para submissão de artigos. Desta vez, não apenas lançamos a expectativa de que nosso reencontro no número 64 da Leitura seja breve, como também o confirmamos com as últimas mudanças anunciadas.

Jozefh Fernando Soares Queiroz

Núbia Rabelo Bakker Faria

Editores 


\section{Referências}

ARAÚJO, Ronaldo Ferreira de; PEDRI, Patricia. Perfil dos periódicos científicos produzidos pelas instituições de ensino superior de Alagoas. Ciência da Informação em Revista, Maceió, v. 6, número especial, p. 71-80, fev. 2019.

MOURA, Denilda. Apresentação. Leitura, Maceió, n. 43-44, jan./dez. 2009.

PIOTR, Trzesniak. A estrutura editorial de um periódico científico. In: SABADINI, A. A. Z. P.; SAMPAIO, M. I. C.; KOLLER, S. H. (org.). Publicar em psicologia: um enfoque para a revista científica. São Paulo: Associação Brasileira de Editores Científicos de Psicologia; Instituto de Psicologia da Universidade de São Paulo, 2009. 